\title{
Health Care Transitions for Children with Sickle Cell Disease: Interventions, Perspectives of Health Care Providers and Caregivers
}

\author{
Orak Hücreli Hastalığı Olan Çocuklarda Sağlık Bakım Geçişleri: Müdahaleler, Sağlık \\ Bakımı Sağlayıcıları ve Bakıcılarına Bakış Açıları
}

\author{
(1) Umar Idris Ibrahim¹, (D) Adam Yau1, (1) Mainul Haque² \\ ${ }^{1}$ Bayero University Faculty of Pharmaceutical Sciences, Department of Pharmacology and Therapeutics, Kano, Nigeria \\ 2Pertahanan Nasional Malaysia (National Defence University of Malaysia), Faculty of Medicine and Defence Health University, Department of \\ Pharmacology, Kem Perdana Sungai Besi, Kuala Lumpur, Malaysia
}

\begin{abstract}
The incapacitating episodic complications associated with the Sickle Cell disease (SCD) limit the opportunities of those SCD patients in education, societal roles, career options, and quality of life, leading to an increase in under-5 mortality. The United Nations included the reduction of newborns and children under-5 mortality among the Sustainable Development Goals. Healthcare providers and caregivers are often involved in the process, have their own perceptions, and challenges. This paper aimed to review relevant studies regarding aspects of health care providers, caregivers, and intervention programs toward strengthening the health care transition in children with SCDs. Literature searched was conducted into PubMed to identify relevant studies. Several intervention programs have been developed and tested, including the transtheoretical model, self-efficacy, theory of planned behavior, and bioecological model, among others. The available literature demonstrates the efficacy of psychosocial, therapeutics, and technological interventions for overcoming SCD-related complications. It was found that the use of wireless and information technology in health care transitions for children with SCD has been gaining more attention. More well-designed studies and holistic approaches are needed to improve the health care transition in children with SCD.
\end{abstract}

Keywords: Transition care, sickle cell disease, pediatric care, transition care intervention, providers

\section{$\ddot{0} Z$}

Orak Hücre hastalığı $(\mathrm{OHH})$ ile ilişkili aciz olan epizodik komplikasyonlar, $\mathrm{OHH}$ hastalarının eğitimdeki fırsatlarını, toplumsal rolleri, kariyer seçeneklerini ve yaşam kalitesini sınırlandırmakta ve 5 yaş altı ölüm oranlarının artmasına neden olmaktadır. Birleșmiş Milletler, Sürdürülebilir Kalkınma Hedefleri arasında yenidoğanların ve 5 yaș altı ölüm oranlarının azaltılmasını içeriyordu. Sağıık hizmeti sağlayıcıları ve bakıcıları genellikle sürece katılır, kendi algılarını ve zorluklarını yaşarlar. Bu yazıda, OHH'li çocuklarda sağlık hizmeti geçișini güçlendirmeye yönelik sağlık hizmeti sağlayıcıları, bakıcılar ve müdahale programlarının yönleriyle ilgili çalışmaları gözden geçirmeyi amaçladık. Aranan literatür ilgili çalıșmaları tanımlamak için PubMed'de gerçekleștirildi. Transteorik model, öz yeterlik, planlı davranış teorisi ve biyoekolojik model gibi birçok müdahale programı geliştirildi ve test edildi. Mevcut literatür, $\mathrm{OHH}$ ile ilgili komplikasyonların üstesinden gelmek için psikososyal, terapötik ve teknolojik müdahalelerin etkinliğini göstermektedir. $\mathrm{OHH}^{\prime} l i$ çocuklar için sağlık hizmetlerinde telsiz ve bilgi teknolojilerinin kullanımının daha fazla dikkat çektiği tespit edildi. OHH'li çocuklarda sağlık hizmeti geçişini iyileștirmek için daha iyi tasarlanmış çalıșmalara ve bütünsel bir yaklașıma ihtiyaç vardır.

Anahtar Kelimeler: Geçiş bakımı, orak hücre hastalığı, çocuk bakımı, geçiş bakımı müdahale, sağlayıcılar

\section{Introduction}

Sickle Cell disease (SCD) is a chronic, inherited hemoglobin disorder associated with lifelong severe and life-threatening complications in neonates, pediatrics, and transitioning young adults (1). These chronic severe complications include anemia, episodic intense pains, stroke, priapism, infections, organ failure, tissue damage, increased morbidity, and premature death while transiting from pediatric to adults. The incapacitating episodic complications associated with the SCD limited the opportunities of those SCD patients in education, societal roles, career options, and quality of life (QoL) (2).

Globally, SCD affects approximately 300.000 newborn babies each year. The traits of SCD have been postulated to confer resistance against malaria, especially among the heterozygous carriers, leading to a higher prevalence in malaria-endemic areas due to selection pressure that promotes SCT for survival (1,3-5). The prevalence and impacts of SCD vary across different parts of the world, with the highest percentage (40\%)
Address for Correspondence/Yazıșma Adresi: Mainul Haque MBBS, MPhil, MSc (UK), CIDDT (UK), FRCP (Glasgow, UK), FRCP (Edinburgh, UK), Pertahanan Nasional Malaysia (National Defence University of Malaysia), Faculty of Medicine and Defence Health University, Department of Pharmacology, Kem Perdana Sungai Besi, Kuala Lumpur, Malaysia Phone: +60109265543 E-mail: runurono@gmail.com ORCID ID: orcid.org/0000-0002-6124-7993

Cite this article as/Atıf: Ibrahim UI, Yau A, Haque M. Health Care Transitions for Children with Sickle Cell Disease: Interventions, Perspectives of Health Care Providers and Caregivers. İstanbul Med J 2020; 21(1): 1-6.

(c) Copyright 2020 by the Istanbul Training and Research Hospital/Istanbul Medical Journal published by Galenos Publishing House.

(C) Telif Hakkı 2020 istanbul Ĕgitim ve Araștırma Hastanesi/Istanbul Tıp Dergisi, Galenos Yayınevi tarafından basıImıștır.
Received/Geliș Tarihi: 03.07.2019 Accepted/Kabul Tarihi: 24.12.2019 
being reported in sub-Saharan Africa, the eastern part of Saudi Arabia, and Central India (2). It has been estimated that $90 \%$ of SCD cases are in developing countries, and more than 90 percent of babies born with SCD in developing countries do not make it to adulthood due to limited resources (6-8). For example, more than half of babies born with SCD in Africa, and central and western India die before adulthood (1). In contrast, more than 90 percent of people with SCD reach adulthood in the United States due to medical advancements and better healthcare $(2,6)$.

The United Nations included the reduction of newborns and children under-5 mortality due to communicable and non-communicable diseases among the Sustainable Development Goals (SDGs). Under the SDGs program, all participating countries are expected to reduce under-5 mortality of not more than 25 deaths per 1.000 live births (9). Bridging the disparities in transition health care in children with SCDS between the developed and developing worlds would go a long way towards achieving the goals of reducing preventable under-5 mortality in the world. Therefore, the objective of this paper is to briefly review and synthesize literature regarding reported perspectives of health care providers, caregivers, and intervention programs toward strengthening the health care transition in children with SCDs.

\section{Intervention and Programs to Address Transition Care}

Transition care in SCD patients has been regarded as a dynamic, multidimensional, deliberate, and active process that ensures uninterrupted affordable and accessible desired health care services. The primary goal of interventions is to prevent and reduce complications, mortality, and improve QoL among people living with the SCD. Therefore, any transition program must adequately prepare pediatric SCD patients to achieve the ultimate goals of uninterrupted quality transition care from pediatrics to adulthood. Several intervention programs have been developed and tested based on the public health and psychological conceptual frameworks, including the transtheoretical model, self-efficacy, theory of planned behavior, and bioecological model, among others. The available literature demonstrates the efficacy of psychosocial, therapeutics, and technological interventions for overcoming SCD-related complications (10). Empirical evidence on the psychological conceptual approaches such as cognitive-behavioral techniques, behavioral change, and social support programs towards improving SCD-related complications have been reported (11). Cognitivebehavioral techniques include cognitive-behavioral therapy, relaxation, cognitive coping strategies, and biofeedback, hypnosis, and interruption strategies. Education and education-related behavioral modification interventions have been regarded as behavioral change programs. The psychosocial intervention approach is sometimes nested in social network support, including support groups, peers, family members, and friends to explore individuals' social networks.

\section{Cognitive-behavioral Interventions}

A few studies explore the Cognitive-behavioral Intervention approaches towards transition health care intervention programs. For example, a qualitative research was conducted in patients with SCD $(n=14 ; 14-24$ years old) and providers $(n=10)$ to evaluate the feasibility of the Social- ecological Model of Adolescent and Young Adult Readiness to Transition (SMART) model for transition intervention program in adolescents and young adults (AYA) with SCD. The investigators reported promising applicability of the social-ecological framework, such as SMART, to improve transition readiness in SCD (12). Accurately, both the providers and young adults with SCD reported several factors that influence the transition process, including episodic and seasonal variability of SCD disease, SCD-related stigma, misconceptions and knowledge gap about the SCD in community, interactions between SCD patients and family members, friends and other components of social networks, knowledge, and skills regarding symptoms and self-management, goal-oriented psychosocial functioning and developmental transition, providers' skills and perspectives of individuals living with SCD (12).

Additionally, another SMART and AYA with SCD models-based qualitative study was conducted among healthcare providers ( $n=13$ SCD experts) to evaluate transition success metrics and determinants of transition success from pediatric to adult healthcare for AYAs with SCD (13). The investigators conducted 60 minutes semi-structured qualitative interviews to explore metrics and facilitators of transition success from the providers' perspectives. A complication-free stable transition, healthcare utilization, continuation care, and QoL are the yardsticks measuring for the success of the health care transition program.

\section{Behavioral Change and Education Interventions}

Multiple studies explored behavioral change and education interventions in the transition from pediatric to adults with SCD. A pre-post and retrospective cohort study with intervention, comparison group, and historical groups was conducted to investigate the effectiveness of transition coordinator program in improving fulfillment after first adult care appointment, integration into adult care by establishing a relationship with the adult care provider, and transition process in the coordinated SCD adolescents compared to the non-coordinated group. The intervention components included a care-coordinator structured pediatric SCD program targeted at pre-adult care at $18^{\text {th }}$ birthday (including discussion and assessment of readiness for transition). Other elements include pilot testing transition activities and involving stakeholders such as parents and providers. This pilot testing was created to provide real-world experience to adolescents with SCD in identifying and establishing care with adult providers. Compared to the control group, the authors reported statistically significant improvement in the adult clinic attendance, service utilization, fulfilling transition, and costeffectiveness for the intervention group (14). Similarly, another pre-post study aimed to investigate the effects of the Duke SCD Transition Program in improving transition readiness and integration into adult care. The investigators reported a significant improvement in SCD knowledge scores, but not in the Sickle Cell Transfer readiness scores among adolescents. Further findings demonstrated gaps in SCD knowledge and concerns about moving to adult care among adolescents with SCD. The difference in knowledge and worries about transition could result in healthcare transition-related stress among transition pediatric to adults with SCD and could lead to a negative impact on health outcomes (15). Stakeholders in the health care transition of pediatric to adults with SCD should educate individuals with SCD patients about diseases, 
management while addressing the raised concerns. A few programs have explored Bandura's social learning theory in an intervention aimed at changing behavior in transition pediatric to adults living with SCD. Correctly, researchers applied the self-efficacy component of Bandura's theory in transitions. The transition from pediatric to adults is not static, so self-efficacy, as defined by Bandura, is the belief in the ability to control behaviors to achieve specific outcomes depending on the situation (16). A prospective cohort study ( $n=4141$ adolescents and their families) was conducted to investigate the effectiveness of self-efficacy on transition in SCD patients (17). The investigators used a Sickle Cell Self-Efficacy scale instrument to assess the level of adjustment among transition SCD patients at the beginning and end of the intervention program (one-year interval). The adjustment level was determined based on pain management, physical and mental symptoms, and health care utilization. These domains were compared with self-efficacy before the intervention and after the intervention to determine to evaluate the relationship between self-efficacy and SCD adjustment. Findings demonstrated significant improvement in physical and psychological symptoms, fewer physician visits among participants with a better self-efficacy after one year (17). This positive correlation reflects the effectiveness of self-efficacy in improving SCD-related health outcomes in adults. This study was limited to adult populations and may not give similar findings when replicated in pediatric SCD patients. Similarly, another study reported significant relationships between self-efficacy, spirituality, and QoL among adults with SCD (18). Furthermore, another study used the hospital-based program to investigate the effectiveness of an educational intervention on the functional ability of the providers (19). The intervention was rooted in a theoretical framework from David Kolb's theory of experiential learning (20). This conceptual framework spanned the cycle of the learning process; concrete-based learning, abstract-based concepts, reflective learning, and active exploration. The investigators used the Youth Acute Pain Functional Ability Questionnaire to evaluate both the providers and SCD patients at the hospital before and after the educational intervention. There was no statistically significant difference between pre and post educational intervention (19).

\section{Technology-based Interventions}

The use of wireless and information technology in health care transitions for children has been gaining more attention. Considering that mobile phones, computers, games, and other devices using wireless technology are readily accessible to the $81-88 \%$ of teens, wireless technology could be a correct approach for addressing SCD related complications (21). An increasing body of evidence explores the use of wireless-based operating devices such as mobile phones to provide various interventions among transition adolescents with SCD. Findings from this study showed significant improvement in symptom management, knowledge, and communication skills between people living with SCD and providers (22). Another study that enrolled 37 transition adolescents and engaged them in text messaging reported a significant definite reduction in SCD-related complications, medication adherence, screening, patient education, and prompt pain and symptom management (23). Other findings from this study include psychosocial support and referral services utilization among children and adolescents living with SCD. Furthermore, in 2012, Jacob et al. (24) conducted a survey among children and adolescents 10 to 17 years of age aimed at investigating the use of smartphones in improving symptoms reporting and communication between participants and providers. The investigators found significant improvements in positive behaviors such as self-monitoring, patient-provider interaction opportunities, and symptom reporting. They also concluded that their smartphone-based e-Diary documentation program could be a cost-effective approach to remove barriers to access to health care, facilitating communication, and appropriate self-management among children and adolescents living with SCD. A randomized clinical trial study conducted among 160 youth aged 12-18 years living with SCD reported improvement in pain self-management and functioning after web and smartphonebased intervention. The smartphone-based intervention was delivered in four components; self-management skills, daily symptom tracking, goal setting, and social community. Another health informationbased intervention study reported promising benefits of information technology towards improving transition care in SCD patients (25). The investigators used a qualitative and quantitative approach to improve transitions of care for patients with SCD. The researcher conducted an environmental scan into the literature to understand what it takes to prepare for and transit from pediatric to adults, focus groups, and key informant interviews among the participants. The participants include SCD patients, providers, caregivers, and IT developers.

\section{Perspectives of Health Care Providers}

The views of the health care providers, essential stakeholders to transition care, are critical. Healthcare institutions often provide transition SCD patients with access to adult provider information and promote their services. However, there are significant variations in assessment and practices associated with the transition of patients' readiness, self-management, and independence among individuals living with SCD. In 2011, Sobota et al. (26) conducted a qualitative study to evaluate transitions practices on patient transition readiness, self-management, logistics, preparation for the transition, and independence of SCD patients across 45 selected pediatric sickle cell clinics. The investigators found that the most significant challenge identified by most of the participated clinics is difficulty in accessing an appropriate adult provider with requisite skills in SCD to transfer pediatric patients with SCD. Also, over $60 \%$ of the involved sickle cell clinics engaged parents, have documented targets for self-management skills, and review the transition readiness of individuals living with SCD as a team. Furthermore, another qualitative study reported that pediatric healthcare providers' perception was negative about transferring pediatric SCD patients to adult care due to the understanding that pain and complication management in adult care is not as good as in pediatric care. Additionally, it was reported that healthcare providers noted the considerable variation in how patients sought care and wish to be treated with disease and complications (27). The available literature demonstrated that the pressing challenge most cited by health care providers is difficulty in identifying an appropriate adult provider with expertise in SCD. There is limited evidence regarding the perspectives of health care providers about the transition in pediatric to adults living with SCD. Well-designed epidemiological studies should be conducted 
to explore the views of health care providers about transition care in the population living with SCD.

\section{Perspectives of Caregivers}

The inputs from caregivers, including parents and family members, are critical to a successful transition among AYA with SCD. The involvement of caregivers has been linked to transition readiness (28). Family members take less responsibility and participation in young adults compared to pediatrics and create a gap in health care and supports (29). A descriptive, correlational study $(n=60)$ aimed to evaluate transition readiness of caregivers and transition individuals with SCD found that parents perceived to be highly responsible for all the healthcare needs for their transition children, but not the young adults with SCD. The investigators also reported significant positive associations between parent involvement in their SCD children transition responsibility and parent's perception of overall transition readiness. However, parent involvement was negatively correlated with the perspectives of an individual with SCD in the study. Therefore, for the better transition process, the responsibility of individuals with SCD should be increased while reducing parent involvement in transitions from pediatric to adults (30). Furthermore, another study $(n=65)$ was conducted to investigate how healthy siblings of individuals with SCD cope psychosocially with SCD-related health and family functioning. The researchers found an increased negative psychosocial stress, such as emergency visits among primary caregivers of family members with SCD (31). Similarly, another study reported that the behavior of parents, family members, and social networks of individuals living with SCD significantly influence clinic visits and hospitalizations (32). These interrelationships in the system of caregivers could have implications in the design and implementation of the transition's intervention program. In 2014, Porter et al. (33) conducted a qualitative study using focus groups to determine the perspectives of caregivers on the transition from pediatric to adult care. The investigators concluded that views of family members are critical in the design and planning of transition from pediatric to adolescents with SCD. They also reported that siblings and caregivers are significantly concerned about medication adherence of family members living with SCD. These findings further highlighted the importance of involving family members in developing and delivery of a successful transition program.

\section{Future Direction and Recommendations}

Great efforts and resources have been applied in health care transitions, especially in the developed world. However, there are several ways to improve transition care and transition programs among children living with SCDs. The identified communication gap between the providers and individuals with SCD should rectify by broadening and incorporating step-by-step approaches for pain management and alleviation of wrong perceptions among the stakeholders involved in health care transition. For example, a clear plan with the division of responsibility should be targeted toward improving direct communication between adult and pediatric providers (34). Another area to address in future research is the difficulty in identifying an appropriate adult provider to transit children with SCD. More deliberate corporative efforts are required from both the pediatric and adult providers towards identifying adult providers who are willing to actively corporate in transitioning individuals with SCD from pediatric to adult health care smoothly. This corporative effort between pediatric and adult providers should be maintained for at least three months after the transition from pediatric to adult health care. The pediatric health care provider could follow up on the transitioning individual with SCD after being transitioned, and the adult providers should consult with a pediatric health care provider to ensure a smooth transition and established care after the transition. Some researchers proposed a more holistic approach to health care transitions. For example, transition programs should consider incorporating vocational and educational needs that occur at the same time as health care transitions (35-37). This synchronization could offer the opportunity for an individual with SCD to acquire life skills toward symptoms management, improving health, QoL, and ability to cope with increasing independence as individual transit from pediatric to adult health care. The incorporation for holistic transition health care would require the recruitment of diverse transition teams that include family members, physicians, nurses, mental health professionals, social workers, and public health practitioners $(38,39)$. Offering transition programs, as part of day camps or through local community organizations, would increase knowledge of health care transition and transition programs leading to improved stakeholder participation and corporation toward holistic transition care. Moreover, the compressive pre-transition assessment was recommended to be one of the criteria for evaluating transition readiness. The synchronization of the traditional age-based health care transition with the pre-transition assessment would develop better transition plans toward making informed decisions about transition care. The pre-transition evaluation should evaluate the family structure, educational status, developmental, and efficacy of individuals with SCD, and should be reviewed annually to ensure benchmarks are being met (36). As part of the pre-transition stage, the scheduling portion of pediatric visits without adults could improve self-efficacy and independent of transitioning children with SCD (34). Organizing separate informal meetings between adult providers and individuals with SCD was suggested to enhance transition health care (38). Another promising recommendation is incorporating wireless and information technology into transition care. For example, smartphones and video modules have been explored to promote self-efficacy and identify patient comprehension of the transition process (40). Similarly, the use of web-based e-Diary before, during, and after a stable transition may improve pain management because most adolescents are using web-based wireless information technology (24). Further research is needed on the outcomes associated with a lack of transition care in the developing world as well as the effects of delaying transition care. There have been needs for consistent measures of transitions across the health system. The regular measures will allow for a better understanding of the transition needs of individuals with SCD and help identify solutions to any challenges. It will also allow for better tracking and long-term assessment of transition care. Incorporate automated message alerts about medication adherence and appointments to remind individuals with SCD about care needs. Significant percentages of adolescents are using wireless technology, including adolescents with SCD. This wireless technology has come to stay, and health care transition stakeholders should fully explore this aspect towards improving healthcare transition 
success, especially among individuals living with SCD. This study is limited by its comprehensive review of nature, which may not represent all the published studies in this area. However, efforts were placed to provide a good summary of what is available in the literature. Moreover, only studies published in the English language were used in this minireview, and therefore, relevant studies published in other languages are not captured here.

\section{Conclusion}

This paper summarized perspectives of health care providers and caregivers, and interventions to assist with transition care for those with SCD and highlighted recommendations to improve transition care for those with SCD. It was demonstrated that more well-designed studies are needed to improve health care transition in children with SCD, as most of the available evidence was from smaller sample studies and surveys. Changes from pediatric to adult care do not just affect individuals with SCD. Healthcare providers and caregivers are often involved in the process, but a more holistic approach is needed in the health care transition of SCD patients. Understanding the perspectives of each of these individuals provides a greater understanding of transition care.

\section{Key Findings}

- Researchers and providers used different measures of transition need among transitioning SCD patients that call for concerted efforts for the use of uniform measures of transition needs.

- It was also demonstrated that health care providers lack the necessary knowledge to provide transitioning individuals, including providers that were interested in providing care.

- Available studies conducted to investigate the association between health outcomes and lack of transition care in the developing world as well as the effects of delaying transition care.

- Incorporation of automated message alerts system about medication adherence and appointments to remind individuals with SCD about care needs demonstrate promising approach towards improving health and QoL. Especially that a significant percentage of adolescents are using wireless technology, including adolescents with SCD.

\section{Acknowledgment}

The authors thank the management of Bayero University for providing the necessary support to produce this work.

\section{Ethics}

Peer-review: Internally peer-reviewed.

Author Contributions: Surgical and Medical Practices - M.H., U.I.I., A.Y.; Concept - M.H., U.I.I., A.Y.; Design - M.H., U.I.I., A.Y.; Data Collection or Processing - M.H., U.I.I., A.Y.; analysis or Interpretation - M.H., U.I.I., A.Y.; Literature Search - M.H., U.I.I., A.Y.; Writing Manuscript - M.H., U.I.I., A.Y.

Conflict of Interest: No conflict of interest was declared by the authors.

Financial Disclosure: The authors declared that this study received no financial support.

\section{References}

1. Modell B, Darlison M. Global epidemiology of hemoglobin disorders and derived service indicators. Bull World Health Organ 2008; 86: 480-7.

2. Piel FB, Patil AP, Howes RE, Nyangiri OA, Gething PW, Dewi M, et al. Global epidemiology of sickle hemoglobin in neonates: A contemporary geostatistical model-based map and population estimates. The Lancet 2013; 381: 142-51.

3. Piel FB, Patil AP, Howes RE, Nyangiri OA, Gething PW, Williams TN, et al. Global distribution of the sickle cell gene and geographical confirmation of the malaria hypothesis. Nat Commun 2010; 1: 104.

4. Cavalli-Sforza LL, Cavalli-Sforza L, Menozzi P, Piazza A. The history and geography of human genes: Princeton university press; 1994.

5. Allison AC. Protection afforded by sickle-cell trait against subtertian malarial infection. Br Med J 1954; 1: 290-4.

6. Grosse SD, Odame I, Atrash HK, Amendah DD, Piel FB, Williams TN. Sickle cell disease in Africa: A neglected cause of early childhood mortality. Am J Prev Med 2011; 41: 398-405

7. Wastnedge E, Waters D, Patel S, Morrison K, Goh MY, Adeloye D, et al. The global burden of sickle cell disease in children under five years of age: A systematic review and meta-analysis. J Glob Health 2018; 8: 021103.

8. Makani J, Ofori-Acquah S, Nnodu O, Wonkam A, Ohene-Frempong K. Sickle cell disease: New opportunities and challenges in Africa. ScientificWorldJournal 2013; 2013: 193252.

9. Rajaratnam JK, Marcus JR, Flaxman AD, Wang H, Levin-Rector A, Dwyer L, et al. Neonatal, postneonatal, childhood, and under-5 mortality for 187 countries, 1970-2010: A systematic analysis of progress towards Millennium Development Goal 4. The Lancet 2010; 375: 1988-2008.

10. Treadwell M, Telfair J, Gibson RW, Johnson S, Osunkwo I. Transition from pediatric to adult care in sickle cell disease: Establishing evidence-based practice and directions for research. Am J Hematol 2011; 86: 116-20.

11. Chen E, Cole SW, Kato PM. A review of empirically supported psychosocial interventions for pain and adherence outcomes in sickle cell disease. J Pediatr Psychol 2004; 29: 197-209.

12. Mulchan SS, Valenzuela JM, Crosby LE, Diaz Pow-Sang C. Applicability of the SMART model of transition readiness for sickle-cell disease. J Pediatr Psychol 2016; 41: 543-54.

13. Stollon NB, Paine CW, Lucas MS, Brumley LD, Poole ES, Peyton T, et al. Transitioning adolescents and young adults with sickle cell disease from pediatric to adult healthcare: Provider perspectives. J Pediatr Hematol Oncol 2015; 37: 577-83.

14. Hankins JS, Osarogiagbon R, Adams-Graves P, McHugh L, Steele V, Smeltzer MP, et al. A transition pilot program for adolescents with sickle cell disease. J Pediatr Health Care 2012; 26: 45-9.

15. Smith GM, Lewis VR, Whitworth E, Gold DT, Thornburg CD. Growing up with sickle cell disease: A pilot study of a transition program for adolescents with sickle cell disease. J Pediatr Hematol Oncol 2011; 33: 379-82.

16. Edwards R, Telfair J, Cecil H, Lenoci J. Self-efficacy as a predictor of adult adjustment to sickle cell disease: One-year outcomes. Psychosom Med 2001; 63: 850-8.

17. Barakat LP, Patterson CA, Weinberger BS, Simon K, Gonzalez ER, Dampier C. A prospective study of the role of coping and family functioning in health outcomes for adolescents with sickle cell disease. J Pediatr Hematol Oncol 2007; 29: 752-60

18. Adegbola M. Spirituality, self-efficacy, and quality of life among adults with sickle cell disease. South Online J Nurs Res 2011; 11. pii: 5.

19. Bernier KM, Strobel M, Lucas R. Assessing the Effect of an Educational Intervention on Nurses' and Patient Care Assistants' Comprehension and 
Documentation of Functional Ability in Pediatric Patients with Sickle Cell Disease. J Pediatr Nurs 2018. pii: S0882-5963(17)30623-1.

20. Kolb DA. Experiential learning: Experience as the source of learning and development: FT press; 2014

21. Huang JS, Terrones L, Tompane T, Dillon L, Pian M, Gottschalk M, et al. Preparing adolescents with chronic disease for transition to adult care: a technology program. Pediatrics 2014; 133: e1639-46.

22. McClellan CB, Schatz JC, Puffer E, Sanchez CE, Stancil MT, Roberts CW. Use of handheld wireless technology for a home-based sickle cell pain management protocol. J Pediatr Psychol 2009; 34: 564-73.

23. Jacob E, Pavlish C, Duran J, Stinson J, Lewis MA, Zeltzer L. Facilitating pediatric patient-provider communications using wireless technology in children and adolescents with sickle cell disease. J Pediatr Health Care 2013; 27: 284-92.

24. Jacob E, Stinson J, Duran J, Gupta A, Gerla M, Lewis MA, et al. Usability testing of a Smartphone for accessing a web-based e-diary for self-monitoring of pain and symptoms in sickle cell disease. J Pediatr Hematol Oncol 2012; 34: 32635.

25. Frost JR, Cherry RK, Oyeku SO, Faro EZ, Crosby LE, Britto M, et al. Improving sickle cell transitions of care through health information technology. Am J Prev Med 2016; 51: 17-23.

26. Sobota A, Neufeld EJ, Sprinz P, Heeney MM. Transition from pediatric to adult care for sickle cell disease: Results of a survey of pediatric providers. Am J Hematol 2011; 86: 512-5.

27. Rouse CM. Informing choice or teaching submission to medical authority: A case study of adolescent transitioning for sickle cell patients. Ethn Health 2011; 16: 313-25.

28. Rutishauser C, Akré C, Surìs JC. Transition from pediatric to adult health care: Expectations of adolescents with chronic disorders and their parents. Eur J Pediatr 2011; 170: 865-71

29. Fredericks EM, Dore-Stites D, Well A, Magee JC, Freed GL, Shieck V, et al. Assessment of transition readiness skills and adherence in pediatric liver transplant recipients. Pediatr Transplant 2010; 14: 944-53.
30. Speller-Brown B, Kelly KP, VanGraafeiland B, Feetham S, Sill A, Darbari D, et al. Measuring transition readiness: A correlational study of perceptions of parent and adolescents and young adults with sickle cell disease. J Pediatr Nurs 2015; 30: 788-96.

31. Gold JI, Treadwell M, Weissman L, Vichinsky E. The mediating effects of family functioning on psychosocial outcomes in healthy siblings of children with sickle cell disease. Pediatr Blood Cancer 2011; 57: 1055-61.

32. Graff JC, Hankins JS, Hardy BT, Hall HR, Roberts RJ, Neely-Barnes SL. Exploring parent-sibling communication in families of children with sickle cell disease. Issues Compr Pediatr Nurs 2010; 33: 101-23.

33. Porter JS, Matthews CS, Carroll YM, Anderson SM, Smeltzer MP, Hankins JS Genetic education and sickle cell disease: Feasibility and efficacy of a program tailored to adolescents. J Pediatr Hematol Oncol 2014; 36: 572-7.

34. Bryant R, Walsh T. Transition of the chronically ill youth with hemoglobinopathy to adult health care: An integrative review of the literature. J Pediatr Health Care 2009; 23: 37-48.

35. Abel RA, Cho E, Chadwick-Mansker KR, D'souza N, Housten AJ, King AA. Transition needs of adolescents with sickle cell disease. Am J Occup Ther 2015; 69: 6902350030p1-5.

36. DeBaun MR, Telfair J. Transition, and sickle cell disease. Pediatrics 2012; 130 926-35.

37. Hopper A, Dokken D, Ahmann E. Transitioning from pediatric to adult health care: The experience of patients and families. Pediatr Nurs 2014; 40: 249-52.

38. Bryant R, Porter JS, Sobota A, Association of Pediatric Hematology/Oncology Nurses, American Society of Pediatri Hematology Oncology. APHON/ASPHO policy statement for the transition of patients with sickle cell disease from pediatric to adult health care. J Pediatr Oncol Nurs 2015; 32: 355-9.

39. Jordan L, Swerdlow P, Coates TD. Systematic review of transition from adolescent to adult care in patients with sickle cell disease. J Pediatr Hematol Oncol 2013; 35: 165-9.

40. Williams CP, Smith CH, Osborn K, Bemrich-Stolz CJ, Hilliard LM, Howard TH, et al. Patient-centered approach to designing sickle cell transition education. J Pediatr Hematol Oncol 2015; 37: 43-7. 